\title{
A caricatura política na concepção libertária do periódico A Plebe (1947-1949)
}

\author{
The political cartoon in the libertarian journal A Plebe (1947- \\ 1949)
}

\section{Zélia Lopes Silva ${ }^{1}$}

\section{RESUMO}

Este artigo discute os sentidos das representações imagéticas (desenhos, caricatura) publicadas em $A$ Plebe, de maio de 1947 a maio de 1949, último período da direção de Edgard Leuenroth. Criado em 1917, o jornal, amparado nos princípios libertários, configurou-se em esfera pública própria para o mundo do trabalho ao discutir os problemas que os trabalhadores enfrentavam em seu cotidiano. O periódico imprimiu fustigadas críticas às elites do país e combateu, sem trégua, o sistema capitalista - qualificado de parasitário, violento e expropriador do proletariado -, ajudado pelas encenações mistificadoras e, igualmente violentas de seu braço religioso expresso nas ações da Igreja Católica cujo combate foi sistemático.

Palavras-chave: Imprensa libertária; Caricatura libertária; Jornal A Plebe; Anticlericalismo; Caricatura; Brasil.

\section{ABSTRACT}

This article discusses the meanings of imagistic representations (drawings, cartoons) published in A Plebe (The Plebs), from May 1947 to May 1949, the last period of the Edgard Leuenroth's headship. Created in 1917, the newspaper, supported by libertarian principles, set up as a public sphere suited for the proletarian world because of discussing the problems that workers were facing in their daily lives. The paper printed whipping criticisms against the country's elites and fought, without respite, the capitalist system - qualified as parasitic, violent and expropriator -, supported by mystifying and equally violent enactments from its religious arm, expressed in the actions of the Catholic Church and whose struggle against was also systematic.

Keyword: Libertarian press; Libertarian cartoon; A Plebe newspaper; Anticlericalism; Caricature; Brazil.

1 Zélia Lopes da Silva professora adjunta da UNESP (Assis), diretora do Centro de Documentação e Apoio à Pesquisa (CEDAP/UNESP/Assis) e autora dos livros A domesticação dos trabalhadores nos anos 30 (1990); A República dos anos 30. A sedução do moderno. (Novos atores em cena: os industriais e trabalhadores na Constituinte de 1933/1934(1999) e Os carnavais de rua e dos clubes na cidade de São Paulo. Metamorfoses de uma festa (19123-1938). 
Neste artigo ${ }^{2}$ as reflexões expostas perscrutam os sentidos das caricaturas publicadas em $A$ Plebe ${ }^{3}$, jornal anarquista fundado em 1917 que passa a se constituir em meio de expressão às correntes libertárias que organizavam os trabalhadores no país. Criado no calor dos embates políticos e manifestações de rua de 1917, em São Paulo, em que pese às muitas interrupções (em virtude das sucessivas prisões de seus diretores/editores, entre os quais Edgard Leuenroth), teve uma longa duração. Interrompido na década de 30, o jornal volta a circular em 1947, período de nova retomada e, também, de sua última fase. Essa volta é considerada emblemática, em decorrência do processo de redemocratização do país após 1945 e da reestruturação das esquerdas. A sua publicação na conjuntura faz parte dessa busca de reorganização dessa tendência política, embora os seus responsáveis reconheçam a grandiosidade dos desafios que terão pela frente.

O jornal A Plebe notabilizou-se pela defesa da causa libertária, usando em suas páginas, além de vários recursos literários, desenhos e caricaturas, para divulgar os seus fundamentos doutrinários e as causas que defendia. Entre elas, destacam-se os problemas que os trabalhadores enfrentavam em seu cotidiano, associando-os ao sistema capitalista (qualificado de parasitário, violento e expropriador do proletariado) e seus representantes, a burguesia e a Igreja Católica, com suas encenações mistificadoras e, igualmente, violentas que davam sustentação aos atos daquela elite burguesa.

Periódicos, a exemplo de $A$ Plebe, por se constituírem em restos de um mundo que não existe mais, que só podem ser relembrados por seus suportes de memória, permitem a reconstrução, mesmo que fragmentária, do imaginário desse grupo social que se valeu de publicações impressas para agregar o proletariado para a defesa de seus interesses, sob as diretrizes dos ideais libertários. Os seus protagonistas avaliaram questões de seu tempo e, pelo registro dessas experiências, forjaram - valendo-se dos embates travados - a memória daqueles que estiveram envolvidos nesse projeto. Com isso, garantiram sua projeção muito além do próprio grupo e do seu tempo. Hoje, esses impressos carregam significativa carga simbólica para segmentos da sociedade, por tornar acessível o que pensavam e o que fizeram parcelas desses segmentos sociais que se encontravam às margens da sociedade brasileira e que sofreram as consequências dessa exclusão.

\footnotetext{
2 Este texto inspirou-se nos resultados do projeto de organização da coleção de periódicos que integra o "Canto Libertário", que pertence ao acervo do Centro de Documentação e Apoio à Pesquisa (Cedap), da FCL/Assis que sistematiza os títulos desses impressos, subdivididos em periódicos nacionais e internacionais, no formato jornal e revistas. Esses periódicos foram doados por Jaime Cubero dirigente libertário do Centro de Cultura Social, entidade que deu suporte as atividades do grupo por longos anos. Com a organização e restauração desses periódicos, do Brasil e exterior, como França, EUA, México, Argentina, objetivou-se garantir sua conservação considerando a significativa importância que esses bens passaram a ter para segmentos da sociedade contemporânea, por sua condição de "restos" de um mundo que deixou de existir e que só pode ser relembrado por sua memória, mesmo que arquivística.

${ }^{3}$ A questão da imprensa proletária, nos últimos tempos, projetou-se nas preocupações dos intelectuais. Inicialmente, o trabalho de Ferreira (1988), abriu espaço, muito lentamente, para a discussão desse tipo de impressos. Em seguida, Hardman (2002) traz alguns aportes importantes sobre a cultura anarquista e, em seu âmbito, sua imprensa, e mais recentemente, Cruz (2000) discutiu o assunto em termos mais amplos, mas dedicou, também, reflexões sobre o periodismo dos segmentos populares.
} 
As lideranças libertárias e seus adeptos fundaram periódicos em diversos países e no Brasil não foi diferente. Os seus impressos foram utilizados como "trincheiras de lutas" e de difusão de seus ideais políticos, encorajando o proletariado em prol de sua libertação. Em decorrência desses compromissos, o seu editor tinha por meta garantir que esses valores fossem divulgados e estivessem presentes nos textos publicados, de modo que o seu conteúdo estivesse em consonância com seus princípios e com objetivos que almejavam alcançar.

Em A Plebe, no período analisado, as atividades e matérias concernentes às manifestações proletárias e questões gerais da conjuntura de outras partes do mundo (como a guerra, os governos autoritários e seus efeitos) aparecem ao lado de notícias do Brasil, característica comum a outros periódicos dessa tendência como bem lembra Hadassa Grossman, ao discutir os periódicos libertários do início do século XX. Em artigo intitulado $A$ imagem da mulher na imprensa de esquerda no Brasil, 1889-1922: Uma exposição sumária, Grossman avalia o papel desses impressos para agregar diferentes aspectos que envolvem a causa proletária que iam desde os avisos de greve, boicotes, propaganda de publicações de interesse da corrente política, até a circulação interna desses impressos e os problemas daí decorrentes por causa das distâncias do país, até o que acontecia pelo mundo afora. Diz Grossman (1998, p. 8-9):

\begin{abstract}
Ali encontramos apelos à solidariedade, balanços sobre a coleta de fundos, avisos sobre as chamadas de greve, ao boicote e a outras manifestações operárias. Anúncios, propagandas e publicidades sobre outras publicações de caráter militante em favor do proletariado, anúncios de brochuras, panfletos e livros publicados separadamente, enfim, todos os tipos de informação ali figuravam. As atividades e notícias que concerniam às manifestações operárias no mundo inteiro apareciam ao lado de notícias de acontecimentos de outros estados do Brasil. As notícias chegavam, neste caso, seja de dois centros industriais ainda em formação, Rio de Janeiro e São Paulo, seja do meio rural e de plantações isoladas. Os periódicos eram também distribuídos nos lugares os mais distantes, constituindo muitas vezes e desta maneira, o único meio de conhecimento e de contato do qual dispunham os colonos, fossem eles imigrantes ou brasileiros.
\end{abstract}

Algumas dessas observações ainda são válidas para a imprensa libertária da década de 1940. Porém, vale a ressalva de que essas publicações periódicas das primeiras décadas do século XX enfrentavam também a pluralidade linguística além das distâncias do país. A falta de domínio de uma língua comum era uma realidade, considerando-se a heterogeneidade do proletariado nos principais centros industriais brasileiros, com significativos contingentes de estrangeiros. É exemplar o caso de São Paulo que recebeu trabalhadores 
provenientes da Itália, Espanha, Alemanha, Polônia, Japão, etc ${ }^{4}$. Certamente, essa questão não se coloca para os anos 40 do século $\mathrm{XX}$, uma vez que a composição do mercado de trabalho brasileiro apresenta diferenças marcantes em relação aos anos anteriores, com a sucessiva incorporação de trabalhadores nacionais aos quadros do mercado de trabalho formal. Essas mudanças são evidentes em São Paulo com a integração recorrente dos trabalhadores nacionais a esse mercado ${ }^{5}$, os quais se somam àqueles de origem estrangeira $\mathrm{e}$ seus descendentes. Porém, independente dos sotaques, o domínio da língua portuguesa se generaliza entre os dirigentes desses impressos e os trabalhadores, os almejados leitores do periódico.

Nessa conjuntura após a guerra de 1939-45, a adesão à causa libertária coloca-se como uma significativa utopia, da mesma forma que conseguir leitores ${ }^{6}$ para o jornal, considerando-se as mudanças ocorridas no país e no campo das esquerdas, com o fortalecimento dos comunistas a partir de então. Mesmo assim, os libertários procuram articular-se em torno de instituições já consagradas, que eram referências para o grupo e para o cenário político das oposições de esquerda, como o Centro de Cultura Social, sediado em São Paulo e o jornal A Plebe.

Essas instituições libertárias mencionadas apresentam-se na conjuntura com o firme propósito de aglutinar os seus militantes e simpatizantes e, também, valendo-se de atividades programadas, angariar novos adeptos. O jornal, por sua vez, para cumprir os seus objetivos, relembra a memória de suas lutas em recorrentes matérias recuperando a trajetória do impresso, de seus organizadores e líderes, desde a sua criação. Traços desse processo serão expostos nesse texto, sem perder de vista que o foco dessa análise centra-se na imagética publicada, de 1947 a 1949 nesse periódico, com base em dois eixos temáticos: os seus princípios doutrinários e as críticas ao sistema capitalista, expressas na degradação dos trabalhadores e no ataque aos opositores (a burguesia e os representantes da Igreja Católica) usando linguagem caricata.

Mas, qual era o perfil específico desse jornal e quem o criou?

\footnotetext{
${ }^{4}$ A imigração de diferentes partes do mundo foi pesquisada por autores diversos. O texto de George Andrews (1998) permite que tenhamos uma ideia geral do debate sobre o assunto. Já sobre a imigração não branca o livro de Jeffrey Lesser (2001) e o livro sobre a imigração francesa, ainda pouco estudada no Brasil, coordenado por Tania de Luca e Laurent Vidal (2009, p. 27-42), dão a dimensão dos problemas enfrentados pelos anarquistas para lidar a com diversidade de interesses e de expectativas dos trabalhadores que compunham a classe operária brasileira nessa conjuntura de após guerra.

${ }^{5}$ A bibliografia especializada enfatiza essas mudanças na composição do mercado de trabalho após 1930, em decorrência da incorporação de contingentes significativos de migrantes vindos de outros estados da federação, notadamente para São Paulo. Consultar sobre o assunto: (BATALHA, 1998, p. 145-158).

${ }^{6}$ Os problemas do jornal não se resumiam apenas a escassez de leitores. As dificuldades maiores eram os parcos recursos para sua publicação, motivo de preocupação do grupo de editores, recorrentemente assinalada pelo jornal. Tanto é que, em 01/08/1947 (p. 1), o jornal abre campanha para conseguir 5.000 assinantes, meta considerada fundamental para viabilizar sua publicação quinzenal. Porém, essa meta não foi alcançada, o que coloca o periódico em constante vulnerabilidade (A Plebe, 01/05/1947, p. 1; 01/08/1947, p.1; 15/12/1947, p.1).
} 
O periódico A Plebe foi fundado em junho de 1917 por Edgard Leuenroth ${ }^{7}$ (tipógrafo e jornalista que defendia os princípios libertários), por ocasião do movimento grevista ${ }^{8}$ do proletariado de São Paulo que convulsionou a cidade, por vários dias, motivo de aborrecimento para as elites e autoridades locais. Pelo papel desempenhado na conjuntura, acabou por destacar-se entre os periódicos de igual perfil, editados naquela década. Apesar das recorrentes interrupções por problemas políticos de seus responsáveis, sempre voltou à cena, cessado o impedimento como ocorrera em 1933 e em 1947. Em 1933, por exemplo, Edgard Leurenroth e Rodolpho Felippe, os seus redatores, publicam o exemplar desse ano. Porém, em seguida, o Jornal deixou de circular, por alguns anos, em decorrência de novos problemas políticos enfrentados por seus responsáveis e de novas ameaças de prisões. Ressurgiu numa nova fase, em $1^{\circ}$ de maio de 1947, ano 30 do Jornal e coube, novamente, a Leurenroth a sua "direção interina" que deveria cessar em maio de 1949, conforme noticia o próprio periódico ${ }^{9}$. A data é emblemática por ser consagrada à luta do proletariado contra as injustiças sociais, tendo como fato simbólico o massacre de trabalhadores em Chicago, que resultou em prisão perpétua, condenação à morte e deportação de lideranças do movimento.

O editor e diretor de $A$ Plebe, em 1947, define o seu perfil ao colocar na primeira página, do lado esquerdo, a vinheta "PELA LIBERDADE, COM O ANARQUISMO" que elucida os seus compromissos políticos e doutrinários. E, do lado direito, é inserido em destaque frase de um pensador de projeção que, no entendimento de seu editor, traduz os ideais libertários. No caso em questão, a citação de autoria de Giovani Bovio, em proeminência, reinaugura o jornal e volta-se aos seus fundamentos doutrinários: "Anárquico é o pensamento e para a anarquia caminha a História". Essas chamadas explicitam para o leitor, sem qualquer ambiguidade, os seus propósitos políticos. Na página de abertura aparece o editorial "Voltando à luta", na qual os seus responsáveis esclarecem ao público que o periódico está de

\footnotetext{
${ }^{7}$ Edgard Frederico Leuenroth (nasceu em Mogi Mirim, em 31 de outubro de 1881 e faleceu em São Paulo, em 28 de setembro de 1968) foi um tipógrafo, jornalista, arquivista e propagandista, um dos mais destacados anarquistas do período da Primeira República brasileira. Fundou diversos jornais e colaborou em diferentes funções em outros periódicos. Esteve envolvido com os periódicos $O$ Boi, O Alfa, Folha do Braz, O Trabalhador Gráfico, Portugal Moderno, $A$ Terra Livre, A Lucta Proletária, A Folha do Povo, A Lanterna, A Guerra Social, O Combate, A Capital, Eclectica, Spartacus, A Plebe, Romance Jornal, Jornal dos Jornaes, A Noite, Ação Libertária e Ação Direta. Foi também fundador de diversas entidades vinculadas à imprensa, entre estas o Centro Typographico de São Paulo, a União dos Trabalhadores Gráficos, a Associação Paulista de Imprensa e a Federação Nacional da Imprensa. (Arquivo Edgard Leuenroth. In: www.ifch.unicamp.br, acessado em 19 de abril de 2007). No verbete do "Canto Libertário", A Plebe é sintetizada na ficha catalográfica, na qual aparecem os dados sobre os seus editores, número de página, endereço, os colaboradores, a existência ou não de ilustração, diagramação e as características principais que definem o seu perfil. Nessa descrição vêse que o jornal possui algumas colunas fixas, tais como: "Pelo Mundo Anárquico", "pequenas notícias das movimentações em outros países"; "O Anarquismo em Prática", reflexões acerca do movimento anarquista brasileiro e estrangeiro; "Correio Plebeu", agradecimento pelas doações em dinheiro e sugestões enviadas à redação. No alto da página inicial sempre há a citação de um pensador libertário. Vários exemplares apresentam a divulgação dos trabalhos desenvolvidos no Centro de Cultura Social de São Paulo. (www.cedap.assis.unesp.br - Acesso em: 8/4/2010).

${ }^{8} \mathrm{~A}$ análise das greves dessa conjuntura, de diversas categorias de trabalhadores foi feita por Boris Fausto (1974, p. 79-109).

${ }^{9} \mathrm{Em}$ matéria de $1^{\circ}$ de maio de 1947, p. 7 o "grupo editor" do jornal esclarece que as iniciativas para publicação do jornal são sempre coletivas, mas "há uma exigência legal que determina a indicação do diretor e do gerente". Esclarece que por muitos anos, antes que $A$ Plebe fosse interrompida pela reação, o seu diretor gerente foi Rodolfo Felipe que nessa fase, por impedimento pessoal, deixara o cargo. "Em vista disso, será diretor gerente interino de A Plebe o companheiro Edgard Leurenroth, seu fundador e diretor em outras fases deste porta-voz do anarquismo no Brasil". Esse percurso de luta foi relembrado nesse fascículo em matéria sobre as perseguições sofridas pelos editores do jornal e as dificuldades para sua publicação em decorrência das sucessivas perseguições.
} 
novo na luta, "como a Fénix da lenda (que) ressurge das próprias cinzas"; seguida de outras matérias como: "Agrava-se a situação", "As reivindicações populares", "A publicação regular de "A Plebe". E, uma caricatura, centralizada na parte de baixo da folha sobre a situação do pobre no país e sua relação conflituosa com as elites.

Nesse editorial de maio de 1947, acima mencionado, foi demarcada a trajetória do jornal e de seus colaboradores e os motivos que originaram, em vários momentos, sua interrupção

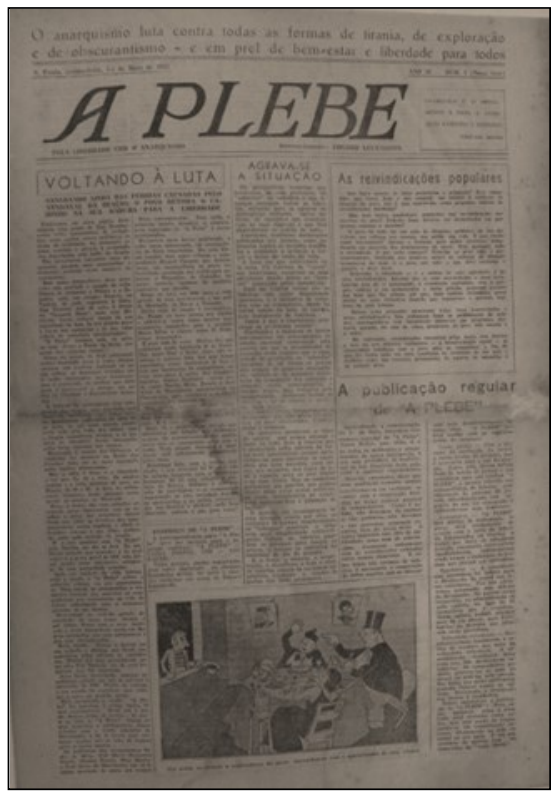
decorrente do empastelamento, dos processos, prisões de uns (diretor e colaboradores) e deportação de outros, como foi o caso de Gigi Damiani. Ao rememorar esse percurso, vai destacando que, além dos empecilhos interpostos à sua veiculação, pela falta de liberdade de expressão no país, muitas das prisões de seus colaboradores resultaram em custos políticos e humanos significativos pela "trilha de sangue que tingiu o próprio jornal", considerando-se que muitos perderam a vida, nesse confronto com os poderosos.

Figura 1 - A Plebe, $1^{\circ}$ de maio de 1947, p. 1

Esse impresso, do ponto de vista técnico, traz uma diagramação moderna e pragmática. Os seus editores aproveitam todos os espaços da folha ${ }^{10}$, em franca superação das dificuldades enfrentadas para sua publicação ${ }^{11}$. Nessa fase, pela campanha aberta em prol do jornal, fica claro que as condições são, igualmente, difíceis. Independente disso, o Jornal dispõe de colaboradores diferentes, até mesmo de artistas do traço, na discussão de temas variados, o que traz um aporte importante ao mesmo. Os desenhos e as caricaturas, de estilos distintos - assinados, anônimos, ou adaptados, com colaborador identificado - trazem outros elementos para discussão de assuntos, às vezes recorrentes, mas abordados de forma peculiar por esses militantes da causa libertária. Os seus propósitos objetivam trazer ao leitor uma compreensão mais eficaz dos problemas tratados, sem perder de vista os princípios libertários norteadores dessas expressões.

\footnotetext{
${ }^{10}$ Os elementos para análise técnica da estruturação de periódicos podem ser detectados por meio do texto de Luca (2005, p. 111-153).

${ }^{11} \mathrm{Em}$ edições posteriores, ao relembrarem as contribuições de Gigi Damiani para o jornal, na década de 10, é descrita a precariedade das instalações para a edição de $A$ Plebe e as pressões sofridas com ameaças de empastelamento do jornal e as perseguições, inclusive de integrantes da sociedade civil, como os filhos das elites, estudantes do curso de Direito. Em 1947, as dificuldades materiais continuam nessa nova fase. Em várias matérias o seu editor e diretor Edgard Leuenroth na coluna "A Publicação de 'A Plebe" faz apelo para que os seus integrantes se engajem na campanha para arrecadar os "tostões" necessários a manutenção de suas edições que deveriam sair nos dias 1 e 15 de cada mês, em revezamento com o jornal Ação Direta, do Rio de Janeiro, meta essa nem sempre cumprida pelo jornal (A Plebe, $1^{\circ}$ de maio de 1947, p. 1).
} 
Independente das especificidades desse tipo de linguagem, as imagens localizadas em $A$ Plebe são usadas para debater/ilustrar temas considerados relevantes pelo periódico e, por isso, sempre que possível, serão analisados conjuntamente, mesmo considerando que são linguagens (texto/imagem) que têm os seus próprios códigos de percepção e de leitura. Neste texto, as imagens serão lidas como crônicas políticas não convencionais, sobre temas do cotidiano do país e do mundo que abordam questões como o $1^{\circ}$ de maio, a guerra, as negociações de paz, o fascismo, a problemática habitacional, a Lei de Segurança Nacional e assuntos doutrinários. Ou seja, temas gerais da conjuntura e aqueles atinentes ao mundo do trabalho cujas imagens carregam, em seus traços, elementos caricatos que variam entre a hipérbole e o grotesco.

A leitura das imagens caricatas dos vários temas discutidos pelo jornal exige que sejam esclarecidos alguns traços conceituais da essência dessa expressão artística, cujo núcleo é o exagero que pode assumir várias gradações. Vladimir Propp (1992), em Comicidade e riso, explana que a caricatura pode ter como foco o exagero do pormenor. Toma-se um pormenor, um detalhe; esse detalhe é exagerado de modo a atrair para si a atenção exclusiva, enquanto todas as demais características de quem ou daquilo que é submetido à avaliação caricatural, a partir desse momento, são canceladas e deixam de existir. Ainda nessa linha de argumentação, esclarece Propp que existem outros tipos de exageros que interessam às nossas reflexões. A hipérbole (que é uma variedade de caricatura) e o grotesco. Na caricatura ocorre o exagero de um pormenor, na hipérbole, do todo. A hipérbole é ridícula somente quando ressalta as características negativas e não as positivas. Já o grau mais elevado e extremo do exagero é o grotesco. Extrapola os limites da realidade e penetra no domínio do fantástico. O grotesco é cômico quando, como tudo que é cômico, encobre o princípio espiritual e revela os defeitos.

O uso desses recursos visa acionar, com base em elementos jocosos e debochados, críticas às personagens representadas e aos seus valores, de tal forma que não haja dúvidas sobre as mensagens veiculadas e sua apreensão pelos leitores. $O$ sentido desse embate promovido por esses protagonistas é contrapor-se às práticas de marginalização social, impostas à maioria da população trabalhadora, travando batalhas simbólicas e de ação direta, a partir de greves, em defesa de temas de interesse de seus afiliados visando ao forjamento de uma sociedade livre, sem exploradores e explorados. Para isso, usaram os recursos mais variados possíveis, entre os quais aparecem as expressões caricaturais e imagéticas, enfatizando o riso de derrisão e o grotesco para a emissão de suas mensagens de contraposição aos seus oponentes.

Certamente o sentido dessa opção não era apenas fazer rir, considerando-se que a caricatura política constitui-se numa linguagem que se afirma como um contra poder; neste caso, ela é usada no combate àqueles que tentam por meio de intimidação, violência e prisões calar o grupo político que defendia outra ordem social sob o primado dos princípios 
libertários. Fausta Gantús (2009, p. 14) sintetiza a questão ao afirmar que "la caricatura política es una forma satírica simbólica de interpretación y construcción de la realidad, una estratégia de accion - de personas e grupos - en las luchas por la producción y el control de imaginários coletivos".

Vê-se, portanto, que o sentido político dessa expressão gráfica manifestou-se na demarcação de um contra poder discursivo que fustigou os poderosos ao acionar mecanismos de rebaixamento resultantes de ridicularização de tudo aquilo que se constituía em seus atributos de poder e de dominação - valendo-se do deboche sobre o desregramento na comilança, da obesidade, do desnudamento da perversão de valores indicando que não passam de falácia as pregações morais e religiosas desses oponentes.

Assim, esses recursos de exposição debochada das características de seus opositores (ou inimigos) foram acionados pelos artistas do traço para colocar em xeque esses protagonistas que representam o mundo capitalista (a burguesia e a Igreja Católica) e suas pretensões de construtores de um "mundo livre e democrático". Os temas usados para esses questionamentos foram muitos, mas a pobreza, expressa nas precárias condições de vida dos trabalhadores (contrapostas à opulência e ao bem viver do outro) foi o mote recorrente nessas circunstâncias. $O$ outro polo do embate volta-se aos valores burgueses, expressos na estruturação do poder, cuja "ordem democrática e política", segundo essa leitura, estruturam-se visando garantir os privilégios de poucos, sob o respaldo da religião católica, outro polo de críticas cáusticas do jornal.

Essa linha editorial perdura até $1^{\circ}$ de maio de 1949. Nesse fascículo, há ligeira alteração em seu layout: na diagramação geral, no seu formato e nas seções. A primeira página, no entanto, apresenta a mesma vinheta "PELA LIBERDADE, COM O ANARQUISMO"; as chamadas principais das matérias e as novas seções tratam de temas que caracterizam a conjuntura.

Figura 2 - A Plebe, São

Paulo, $1^{\circ}$ de maio de 1949.

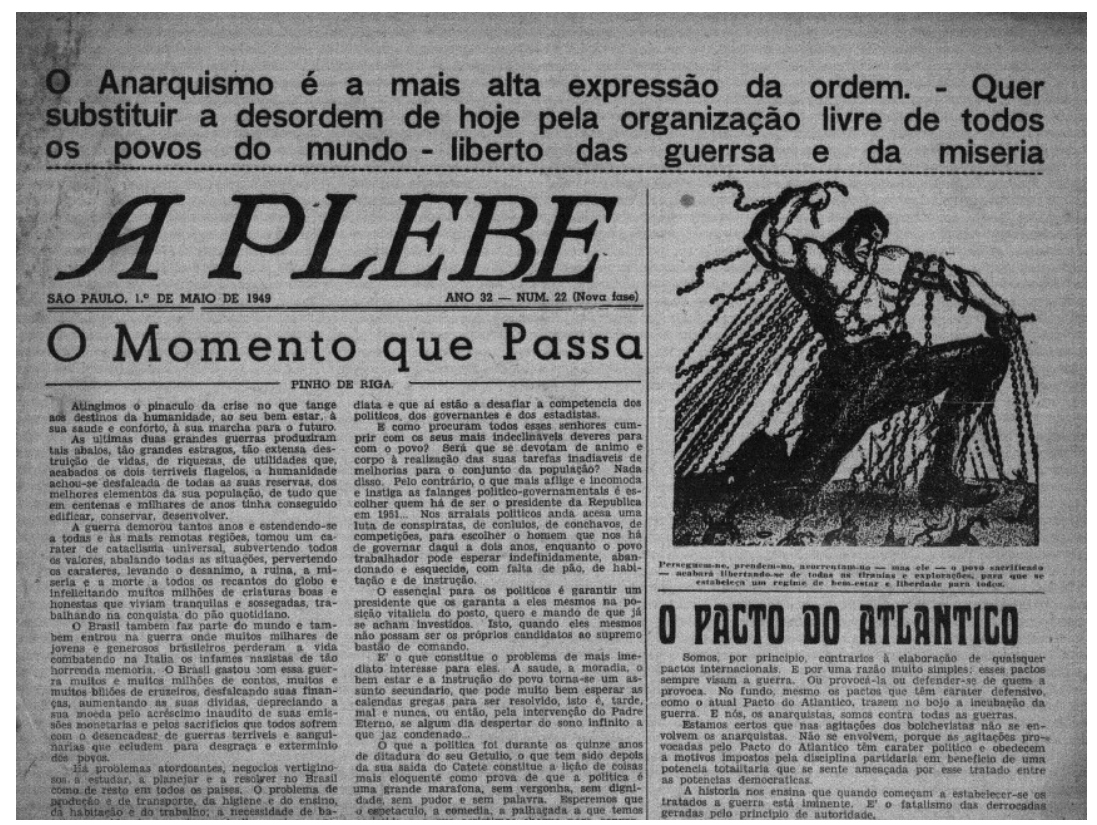


A imagem alusiva ao dia do trabalho, na primeira página, apresenta homens, mulheres e crianças acorrentados e, na página interna, outra imagem de um trabalhador, nomeado de "o povo", indicando estruturação plástica do desenho, diferentemente dos anos anteriores. A legenda da imagem é a seguinte: "Perseguem-no, prendem-no - mas ele - o povo sacrificado - acabará libertando-se de todas as tiranias e explorações, para que se estabeleça um regime

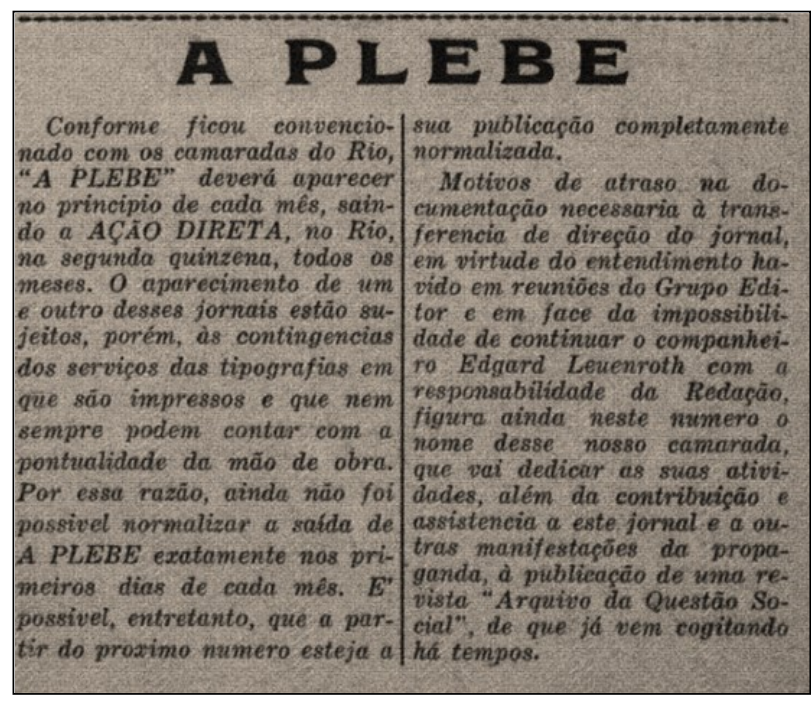
de bem-estar e liberdade para todos"12. No final dessa primeira página, o Grupo Editor anuncia, em matéria publicada em box que Edgard Leuenroth deixará de ser o seu diretor, a partir dessa data e somente está assinando aquele número por motivo de atraso na documentação de transferência da direção do jornal, conforme assinala a notícia abaixo.

Imagem 1 - A Plebe, São Paulo, $1^{\circ}$ de maio de 1949.

Porém, essas alterações não prosseguem, uma vez que A Plebe de 1951 (Ano 33, n. 31nova fase) ainda indica que o jornal está sob a direção de Edgard Leuenroth, apresentando a clássica vinheta e as chamadas de pensadores que se identificam com o anarquismo. Embora haja um texto de crítica à Igreja Católica, não é possível saber se, de fato, Edgard Leuenroth deixara a direção do jornal, como fora anunciado anteriormente. Mas, o anticlericanismo que sempre caracterizara o jornal não teve continuidade nos fascículos seguintes a maio de 1947, sobretudo nas imagens que anteriormente foram usadas para criticar a alta hierarquia da Igreja Católica.

Vale ressaltar que certo estilo de editoria e a abordagem dos temas imprimiram marca específica ao periódico, independente dos assuntos tratados. A sátira foi usada para impor corrosiva crítica aos seus oponentes e, em seu âmbito, o combate anticlerical. Esses traços remetem a Leuenroth que plasmou a sua marca a esse periódico que passou a ocupar papel importante enquanto veículo de oposição aos poderosos, ao se contrapor, de forma enfática e peculiar, em relação às questões conjunturais e aos protagonistas defensores daquela ordem que não tiveram opositores tão contundentes, em outras folhas periódicas e diárias, existentes no período.

Os tópicos a seguir permitem acompanhar as discussões veiculadas pelo periódico e os temas que foram debatidos pelos caricaturistas no período proposto para análise.

\footnotetext{
${ }^{12}$ A Plebe, São Paulo, $1^{\circ}$ de maio de 1949.
} 


\section{Os pobres nas caricaturas de A Plebe}

O tema da pobreza foi recorrente nesse processo, embora o tratamento sobre o assunto não seja prerrogativa do grupo. A conjuntura foi descrita pela historiografia ${ }^{13}$ pelas carências diversas que dificultavam a sobrevivência das classes populares, em decorrência do alto custo de vida e da escassez de gêneros alimentícios básicos necessários à sobrevivência da população, em decorrência dos efeitos prolongados da guerra, dos baixos salários e do desemprego. Também é um momento marcado por muitas manifestações grevistas de diferentes categorias de trabalhadores, tal a defasagem de seus salários, deixando claro que a pobreza no país não foi um tema inventado pelos libertários.

Em seu primeiro número de maio de 1947, A Plebe estampa a caricatura assinada por "LA" que traz à cena a questão da pobreza e o incômodo causado às elites, a exposição do pobre ao seu olhar. $\mathrm{O}$ autor discute $\mathrm{o}$ assunto valendo-se de uma situação delicada, ao flagrar uma família burguesa e seu convidado, um religioso da alta hierarquia da Igreja Católica, banqueteando-se quando são interrompidos por um pedinte que estende o chapéu solicitando uma esmola. A mulher assusta-se com o intruso à janela e os homens escorraçam o homem. Na legenda, "LA" escancara crítica contundente ao dizer que "São assim os tiranos e exploradores do povo: acovardam-se com o aparecimento de suas vítimas”.

Evidencia-se, nessa reflexão, o contraste entre os mundos da riqueza e da pobreza e o alheamento e a violência dos abastados sobre as condições de sobrevivência dos excluídos. $\mathrm{Na}$ cena, espelha-se o horror provocado às elites a abordagem de pedinte em busca de algumas migalhas, ainda mais quando isso ocorre em situação que os flagra em suas comilanças, em frontal escárnio à fome de seu oponente que também se espanta com a reação causada à solicitação de alguns trocados.

Legenda - São assim os tiranos e exploradores do povo: acordavadam-se com o aparecimento de suas vítimas

Figura 3 - A Plebe, $1^{\circ}$ de maio de 1947, p. 1

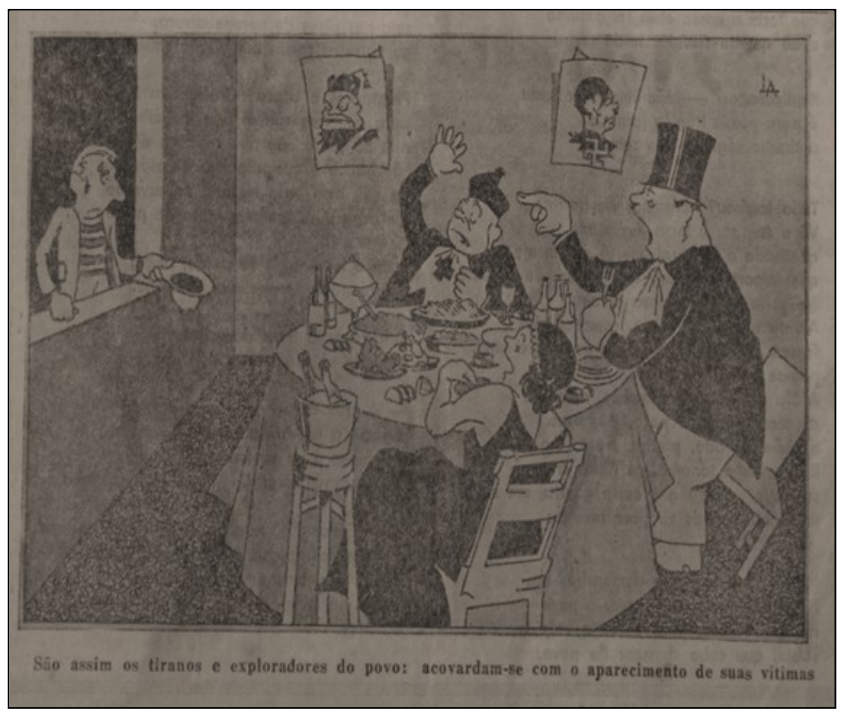

${ }^{13}$ Ver sobre o assunto: (NEGRO; SILVA, 2003, p. 47-96), que discutem o percurso dos trabalhadores no período democrático após 1945, demarcando as mobilizações diversas que ocorrem de 1945 a 1964. 
O desenho traz outro elemento à cena que traduz os alinhamentos políticos desses personagens. Os retratos de Stalin e Hitler (marcado pela suástica), este último já fora de cena, que "enfeitam" a parede do recinto, aparecem como ícones que materializam ideários político-ideológicos combatidos pelos libertários, independente das posições opostas defendidas por esses ícones durante a II Guerra Mundial e dos enfrentamentos nos campos de batalha. Na leitura de $A$ Plebe, esses personagens (e suas ideias) são faces da mesma moeda: encarnam posições reacionárias, hipócritas e violentas que inspiram às atitudes reacionárias dos também protagonistas brasileiros.

A outra face do mesmo problema é a questão da moradia das classes populares, assunto discutido no fascículo de $A$ Plebe, de $1^{\circ}$ de agosto de 1947 , em texto e na Ilustração que

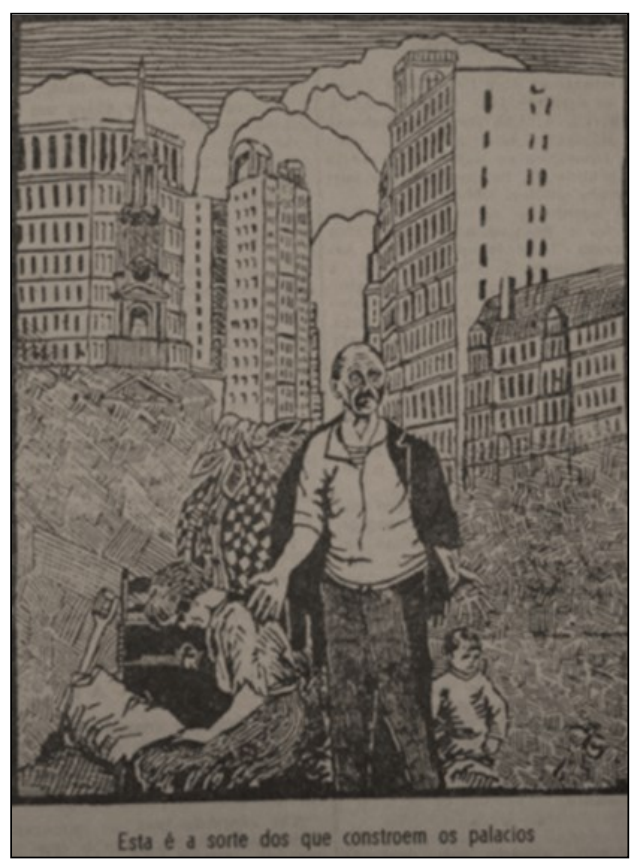
acompanha a matéria. O discurso escrito expõe a situação dos cortiços e demais habitações precárias onde mora a maior parte dos trabalhadores, mesmo que sejam eles os construtores dos refinados palacetes e prédios, residências das elites endinheiradas. O Jornal traz, ainda, para reforçar essa informação, desenho de uma família jogada ao relento, tendo ao fundo os prédios e palacetes das elites. A legenda complementa de forma didática, a mensagem visual que o texto expôs em detalhes: "Esta é a sorte dos que constroem os palácios".

Legenda - Esta é a sorte dos que constroem os palácios

Figura4 - A Plebe, 1/8/1947, p. 1

Vê-se, nesse desenho, que explora o dramático episódio de despejo de um casal marido, mulher e um filho pequeno - , a demarcação das diferenças sociais existentes e as contradições entre quem produz e quem se apropria do resultado do trabalho. A dramaticidade da cena pode ser acompanhada pela postura do homem, cuja expressão facial fechada e sofrida e mãos espalmadas, indicam sua perplexidade e impotência. A mulher, sentada, não consegue esconder a dor e o sofrimento em face à situação de miséria e abandono em que se encontram. A criança, embora na cena, é colocada à margem, propositalmente, para indicar sua impossibilidade de compreensão do que se passa na família.

Esse contradiscurso coloca em xeque a propalada ordem democrática ao deixar exposta que os seus beneficiários são poucos, em detrimento dos demais integrantes da sociedade 
brasileira que vivem as agruras dos baixos salários, do desemprego, da falta de moradia e do alto custo de vida que corrói os seus parcos ganhos.

\section{Além das denúncias: A Liberdade conduzindo o povo - A disputa pela memória do $1^{\circ}$ de maio}

O jornal $A$ Plebe, no entanto, não ficou nas denúncias. Em algumas matérias, que vêm acompanhadas de caricatura para reforçar a mensagem, projetam-se a perspectiva de luta. $\mathrm{O}$ fascículo relativo ao $1^{\circ}$ de maio desse ano de 1947 rememorou o histórico de lutas travadas pelos trabalhadores, em âmbito internacional e, também, no Brasil, por se tratar de data emblemática na trajetória dos movimentos sociais. Porém, não perde de vista o propósito encetado pelas elites, de sua transformação em "festa do trabalho".

Contrapor-se a essa perspectiva era o significativo desafio dos libertários na conjuntura de pós-guerra. Suas reflexões apareceram na matéria sob o título "Manifestação Internacional dos trabalhadores como afirmação de seus direitos" (A PLEBE, 01/05/1947, p.03), com ilustração de uma imagem anônima, no centro da página, de trabalhadores de macacão e em trajes militares, segurando no mastro da bandeira desfraldada, formado pelo número 1 , alusivo ao $1^{\circ}$ de maio.

Figura 5 - A Plebe, $1^{\circ}$ de maio de 1947, p. 3

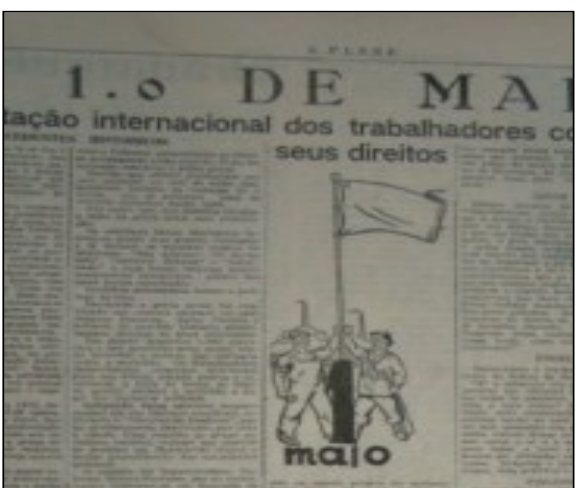

Em 1948, as discussões tomaram outro rumo. No centro da matéria, da primeira página do periódico de $1^{\circ}$ de maio de 1948, Liberdade, uma jovem mulher, empunha "a bandeira da AIT - Associação Internacional dos Trabalhadores" ( $1^{a}$ Internacional) classificada na chamada abaixo de a "bandeira da solidariedade" (de classe). Ela conduz homens aguerridos, em marcha, com os braços erguidos e as bocas entreabertas que sugerem manifestações verbais (palavras de ordem ou alguma canção/hino, talvez a Internacional?!) seguindo o seu comando. Os punhos da jovem exibem pedaços de correntes que simbolizam os grilhões rompidos e a força de seu poder conferido pela união de todos, em torno de uma causa comum.

A postura, a expressão facial e a veste esvoaçante - indicando leveza de seus movimentos e do estado de espírito - da alegórica e resoluta jovem combatente, lembram a representação clássica, alusivas às jornadas de 1830, " $A$ Liberdade guiando o povo", de Eugène Delacroix, metáfora em homenagem à mulher revolucionária francesa engajada na luta para romper os grilhões contra a opressão aristocrática e os seus suportes de 
dominação, como analisa, em outro contexto, José Murilo de Carvalho no livro A Formação das Almas. O imaginário da república no Brasil (CARVALHO, 1990, p.76.). Porém, na representação em pauta a jovem não usa o barrete frígio e, também, os pés e os seios não estão à mostra, o que indica sua singularidade em relação àquelas representações - da República, da Liberdade, etc - já sacralizadas pelos pintores revolucionários do século XIX e, recorrentemente apropriadas e reinterpretadas, a sua maneira, para divulgar causas assemelhadas em outros países.

Essa representação, contudo, sinaliza o embate de duas concepções existentes na conjuntura: a da tradição do $1^{\circ}$ de maio - dia consagrado aos mártires do trabalho que os libertários e as demais correntes trabalhistas reverenciavam pelo mundo afora -, plasmada na luta; e, a invenção de uma "nova tradição", forjada ao longo do governo Vargas, entre 1930-1945, que buscava associar sua imagem à defesa dos pobres e dos trabalhadores, sendo o $1^{\circ}$ de maio, pela sua significação, o marco para enfatizar esse vínculo ${ }^{14}$.

Em combate a essas investidas, $A$ Plebe aciona a imagem bélica da Liberdade que traz a sua potência revolucionária, para contrapor-se e reforçar a batalha pela memória ${ }^{15}$ do trabalho sintetizada na data símbolo $1^{\circ}$ de maio, o dia consagrado à lembrança das lutas proletárias contra a exploração e a violência de classe, cuja disputa para consagrar outro sentido avança de forma contundente no país. O texto de A Plebe, acima da imagem, reafirma o duelo para garantir a continuidade de sua significação ("de dia de luta") ao contra-atacar a tentativa oficial (das elites ou dos governos) de mudar o seu perfil para "festa do trabalho", denunciando-a como ação de "mistificadores", como reafirma na legenda: "o trabalho vive escravizado e os escravos não costumam festejar sua escravidão" (A PLEBE, 01/05/1948).

Para o conjunto dos trabalhadores, portanto, a adesão ou não a uma delas passava pela difícil escolha: Qual memória consagrar? E, qual o significado e desdobramento dessa escolha em seu cotidiano?

\footnotetext{
${ }^{14}$ O "queremismo", movimento ocorrido em 1945, com apoio dos comunistas, que defendia a continuidade de Vargas no poder expressaria, portanto, a vitória dessa perspectiva de congraçamento entre as classes tendo na celebração "festiva" do $1^{\circ}$ de maio, sua expressão mais efetiva, por contrapor-se às tradicionais manifestações libertárias que reafirmavam as lutas travadas pelos trabalhadores ao longo dos séculos. Informações mais específicas sobre o queremismo e o primeiro de maio, consultar: (FERREIRA, 2003, p. 13- 45). Sobre o "1 de Maio", ver: (BILHÃO, 2011, p. 71-92). ${ }^{15} \mathrm{Cf}$. sobre o assunto: (POLLAK, 1992, p. 200-212).
} 


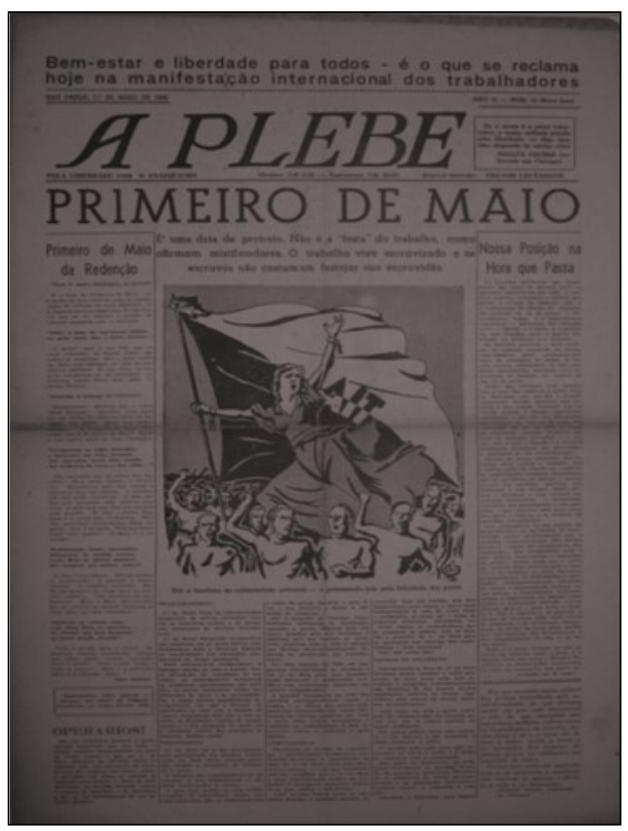

Legenda - Sob a bandeira da solidariedade universal - o proletariado luta pela felicidade

Figura 6 - A Plebe, $1^{\circ}$ de maio de 1948

Em $1^{\circ}$ de maio de 1949, A Plebe, sob nova direção, traz em página interna, o desenho de um homem robusto amarrado em pesadas correntes (Figura 2), com texto dizendo que esses grilhões não se constituem em problemas porque serão rompidos pelo povo.

\section{A Liberdade em defesa da Lei de Imprensa}

Legenda - O conluio reacionário preparou o monstro para o sacrifício da Liberdade

Figura 7 - A Plebe, 1/8/1947, p. 1

A "Liberdade" não aparece apenas nesse cenário de defesa dos oprimidos. Ela é acionada para discutir outras dimensões de cerceamento, tais como a liberdade de expressão e de constrangimentos que possam aparecer, em diferentes situações e disfarces. Em agosto de 1947, foi discutida pelo periódico a Lei de Segurança Nacional, matéria ilustrada com uma contundente caricatura, assinada por

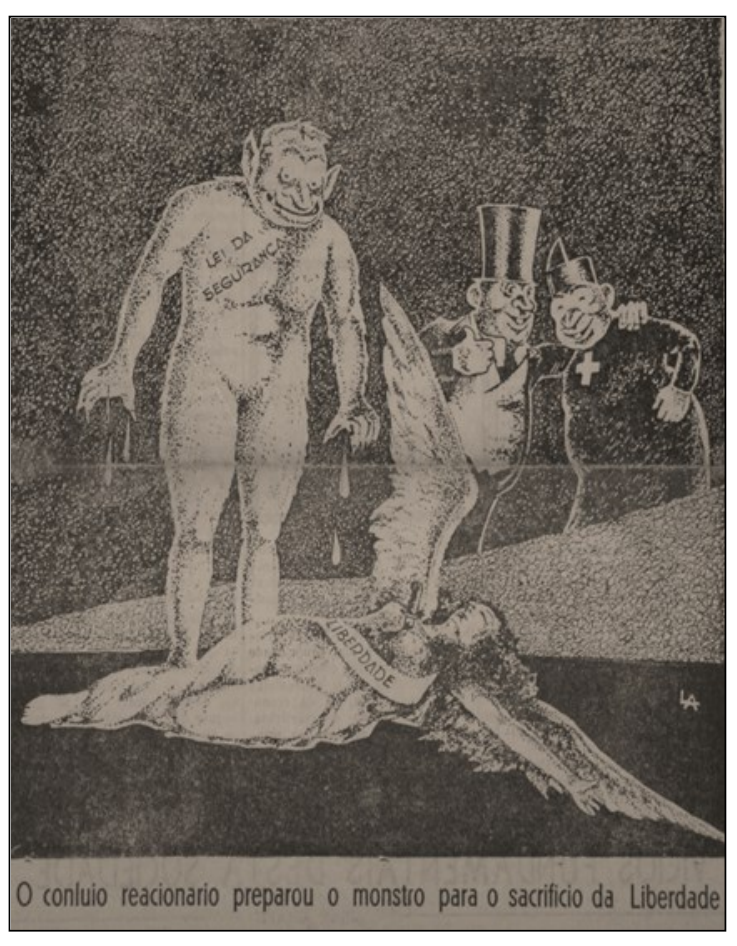
"LA". Nela emergem os protagonistas principais, a burguesia e a Igreja e os motes do embate: A Lei de Segurança e a Liberdade. A LSN é representada por um monstro, cuja face 
embrutecida e animalesca evidencia sua insensibilidade e violência. $\mathrm{Na}$ cena, as suas mãos vertem o sangue de "Liberdade", representada por uma jovem mulher, portando amplas asas, já abatida aos seus pés. Ao fundo, dois personagens representando a burguesia e a Igreja, confraternizam-se sorridentes, o que indica que eles são os responsáveis pela façanha. Tais personagens surgem identificados por seus símbolos específicos, como o fraque e a cartola para o pançudo burguês, e a cruz na batina para o gorducho representante da alta hierarquia da Igreja Católica. Os tipos ali expressos confabulam sobre a medida em questão, demonstrando satisfação com o caminho tomado na sua resolução. Já a personagem LSN traz inscrita no próprio corpo sua identificação. $O$ seu perfil é traçado visualmente como uma figura monstruosa e animalesca, orelhas pontudas, nariz longo e achatado, boca enorme, indicando um sorriso teatral, após o macabro ritual. Essa caracterização é ainda complementada pela legenda que ajuda a esclarecer o significado dessa representação, ao indicar que a LSN imolou a Liberdade que se encontra abatida, sob o olhar dos responsáveis pelo ato de violência.

A estruturação do sistema plástico coloca em evidencia o tom pedagógico do desenho. A figura da Liberdade é representada com suas amplas asas, alegoria supostamente já consagrada no imaginário popular ${ }^{16}$, da mesma forma que o burguês e o religioso, que reiteradamente foram representados na imprensa anarquista portando os signos que os identificam em diferentes situações; nessa cena, eles aparecem devidamente caracterizados nos seus traços e no vestuário de forma a não deixar dúvidas sobre suas origens. Outro aspecto que se pode identificar é a dramaticidade da imagem, que a distancia de qualquer veleidade de provocar o riso motejador ao ridicularizar os personagens principais, uma vez que a cena causa repulsa ao leitor e não atitude de zombaria frente ao ato. Nesse sentido, ela

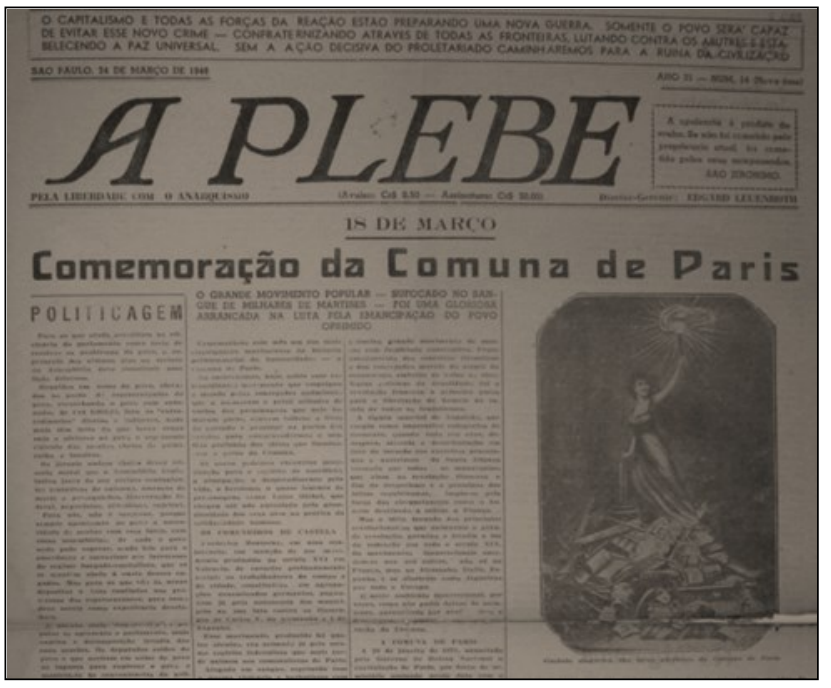
desliza para o campo do grotesco, pela carga dramática que é impressa nessa interpretação, seguindo os preceitos que evidenciam, pela sua negatividade, exagero caricatural tal qual assinala Propp, ao caracterizar o grotesco, na obra citada anteriormente.

Legenda - Símbolo alegórico das lutas gloriosas da Comuna de Paris

Figura 8 - A Plebe, 24/3/1948, p. 1

${ }^{16}$ Os fundamentos teóricos, para compreender as visões de mundo presentes no social podem ser esclarecidos no texto de Baczko (1986). 
No ano seguinte, a manchete de primeira página traz em seu título "18 de março Comemoração da Comuna de Paris novamente a Liberdade é acionada para comemorar essa data considerada "o grande movimento popular - sufocada pelo sangue de muitos mártires - foi uma gloriosa arrancada na luta pela emancipação do povo." Ao lado do texto, a imagem da Liberdade acompanhada da legenda que esclarece tratar-se de "símbolo alegórico das lutas gloriosas da Comuna de Paris" (A PLEBE, 24/03/1948, p.1).

Nessa imagem, Liberdade, em pé sobre um monte de objetos que simbolizam os grilhões rompidos (numa postura que repete as imagens já consagradas, mas com vestes comportadas), ergue uma tocha com uma das mãos a indicar a esperança que se abre para os que procuram se libertar do jugo de opressores.

A Liberdade desta feita reaparece em ação para garantir que a memória de lutas emblemáticas não seja obliterada. Na elaboração aludida, há a busca de consagração de uma memória síntese, das lutas travadas pela plebe em outras jornadas, cuja inspiração nuclear é a Comuna de Paris, o seu principal ícone, que agrega o conjunto de demandas e de valores liberdade, fraternidade e igualdade - , que se sobrepõem às correntes políticas e às ideologias. Esses valores são considerados basilares para o processo de libertação de homens e mulheres sob o jugo da opressão pelo mundo afora que, nessa leitura, estão associados às históricas lutas populares que servem de inspiração à luta pela liberdade, em qualquer dimensão e circunstância.

\section{Os inimigos: A burguesia e a Igreja}

As discussões avançam no sentido de identificar quem são os responsáveis pela opressão e cerceamento da liberdade. No caso em pauta, a burguesia e os representantes da Igreja Católica são considerados os principais protagonistas. O embate travado pelo jornal, em oposição aos seus declarados inimigos, materializa-se na tipificação feita com base na caracterização de alguns de seus traços físicos e, também, nos ícones que os identificam, voltados às suas vestimentas, a exemplo de charges de 1947 e 1948 que expõem um burguês sendo carregado por trabalhadores e outro sentado numa poltrona com os pés sobre sacos (de dinheiro ou outras riquezas). Em outra situação, aparece uma figura andrógina com roupas femininas e um rosto metade homem metade tubarão com os dentes afiados e prontos para morder. 


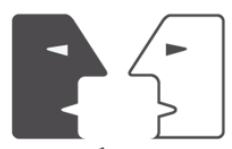

ANTÍTESES

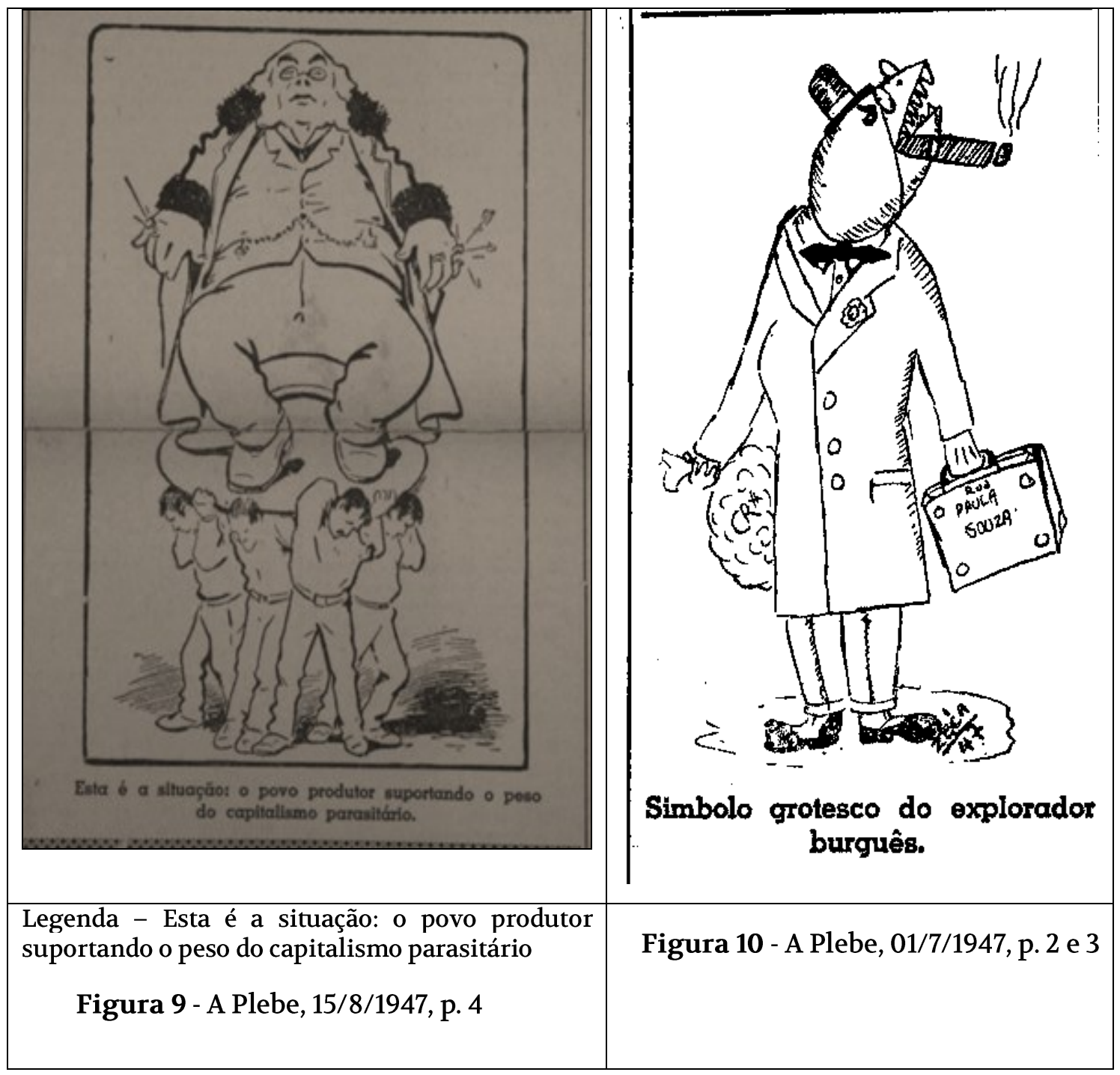




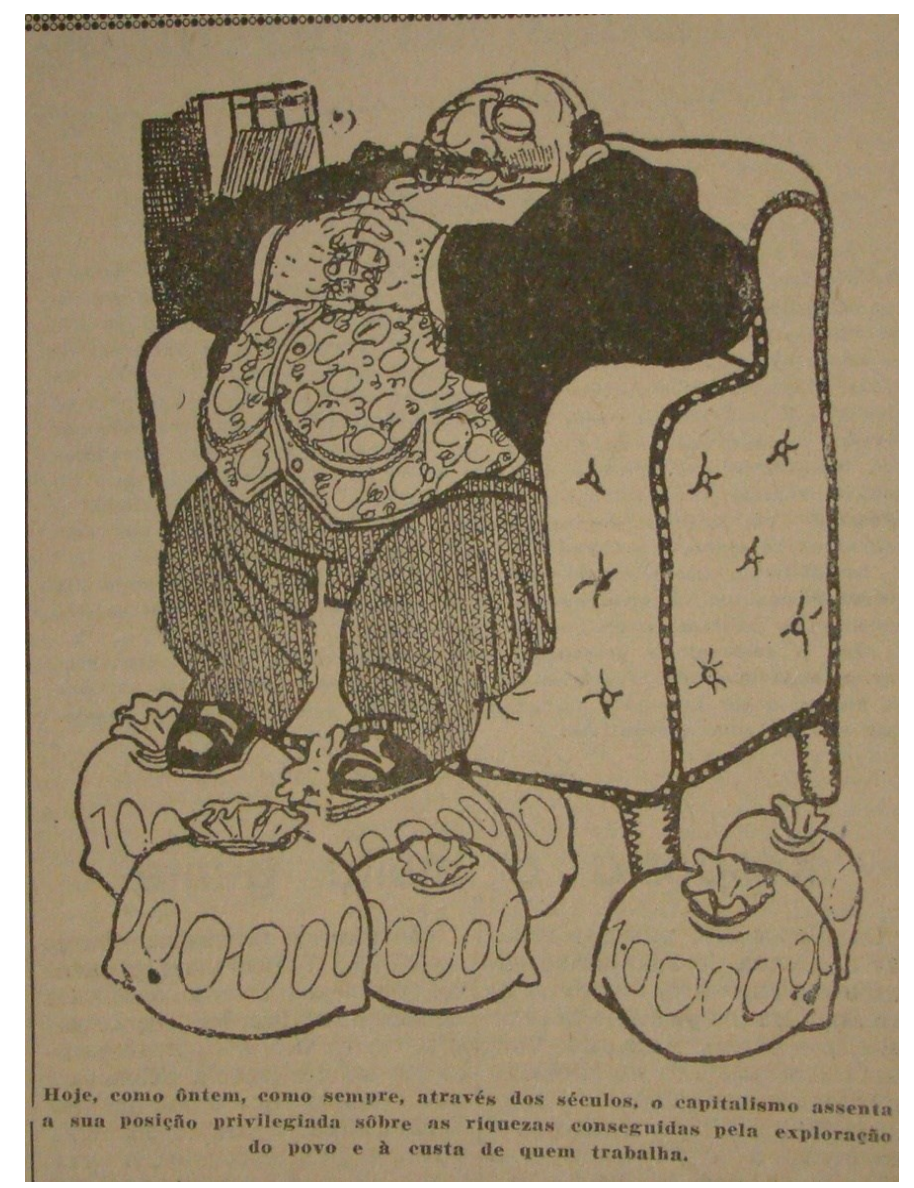

Legenda - Hoje, como ontem, como sempre, através dos séculos, o capitalismo assenta a sua posição privilegiada sobre as riquezas conseguidas pela exploração do povo e a custa de quem trabalha.

Figura 11 - A Plebe,16/7/1948, p. 2 e 4

Na primeira charge (sem assinatura), A Plebe mostra magros trabalhadores carregando em seus ombros um burguês (síntese do capitalismo) que exibe os seus símbolos de riqueza e poder. Essas características estão expressas em suas vestes, na obesidade e nos anéis de brilhante, que faíscam em seus dedos, que na leitura do artista do traço são resultantes da exploração do trabalho dos outros e não do seu próprio esforço.

No desenho, o gordo burguês que vive da exploração dos trabalhadores foi representado com base em elementos que enfatizam dimensões do baixo ventre como a obesidade cujo atributo indica o desregramento e o excesso de comilança, que imprimem o rebaixamento e o descoroamento ${ }^{17}$ dessa personagem, em contraposição às suas distinções e ícones de poder. Além disso, associa esse sujeito e suas práticas, ao capitalismo que é qualificado de

\footnotetext{
${ }^{17}$ Este conceito foi formulado por M. Bakhtin e permite entender situações de crítica derrisória que é infringida ao oponente usando elementos caracterizados como excessos e associados ao baixo ventre. Consultar sobre o assunto: Bakhtin (1987).
} 
parasitário, tal qual aquele que se beneficia de seu funcionamento. O sistema capitalista também é representado por uma figura bissexual. Essa imagem, com terno em formato feminino e uma cabeça, metade homem metade peixe (tubarão) aparece em vários fascículos, com e sem legenda, sempre com bolsa indicando a Rua Paula Sousa e portando enorme charuto entre os dentes.

No ano seguinte, o sistema capitalista é novamente arguido em charge (anônima), na qual um gordo burguês aparece sentado numa poltrona, com os pés apoiados em sacos supostamente de dinheiro e de outras riquezas. A legenda diz o seguinte: "Hoje, como ontem,

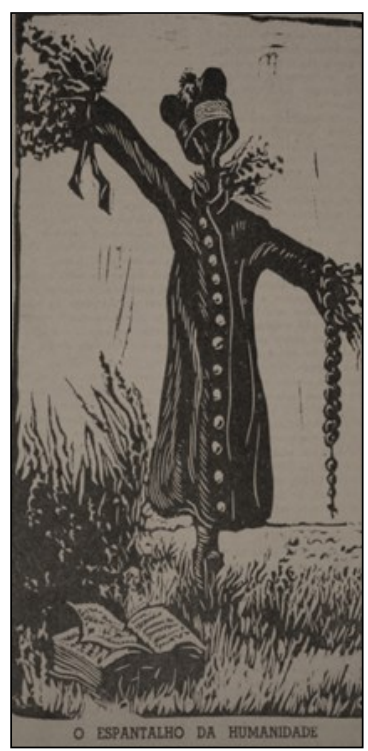
como sempre, através dos séculos, o capitalismo assenta a sua posição privilegiada sobre as riquezas conseguidas pela exploração do povo e a custa de quem trabalha" (A Plebe, 16/7/1948, p. 2 e 4). Os mesmos elementos plásticos foram usados para imprimir a crítica ao capitalismo. Nesse caso, o burguês, além de gordo tem uma aparência envelhecida e está em seu "cochilo" secular, fruto da exploração de quem trabalha que são os responsáveis e os que garantem o sono e as riquezas usufruídas por esses sujeitos que dão sustentação ao sistema capitalista.

Legenda - O Espantalho da humanidade

Figura 12 - A Plebe, 1/10/1947, p. 1

O outro protagonista dessa pugna é a Igreja Católica que se constitui em significativo traço do anticlericalismo de $A$ Plebe. Em suas charges (16 charges ao todo) são tematizadas situações diversas de seus representantes que vão do padre ao Papa, embora ao longo de suas reflexões, o tema também seja abordado de forma específica. Em 1947, por exemplo, o anticlericalismo apareceu no jornal sob a imagem "O espantalho da Humanidade". Trata-se de uma alegoria bastante diferente de outras representações, considerando-se que o assunto é uma crítica direta à religião e não à hierarquia da Igreja e suas alianças de classe. $O$ espantalho, sem rosto e sem mãos, traz os símbolos, de fácil associação, tais como a batina, o terço e o livro aberto (uma bíblia) que indicam tratar-se da Igreja Católica, alvo do combate do periódico.

Porém, a representação sugere, em sua legenda, que não se trata de um fato específico e sim de uma encenação que tem em mira assustar os incautos e ingênuos, tal a sua falta de sustentação e de densidade histórica, e somente os crédulos ouvem suas pregações e temem os castigos anunciados para os "pecadores" que não seguirem as suas prédicas e regras.

As críticas à Igreja apareceram em outras representações que envolvem sua prática cotidiana representada pelo padre, sempre pedindo uma esmola. No caso a esmola era para 
as almas, o que configura a falta de inserção nos problemas vivenciados pela maioria da população que vive em condições de extrema pobreza. Ou, questionando suas alianças políticas com os fascistas brasileiros, mesmo após a guerra, que agarrados à cruz tentam arrastar o proletariado para o campo conservador.

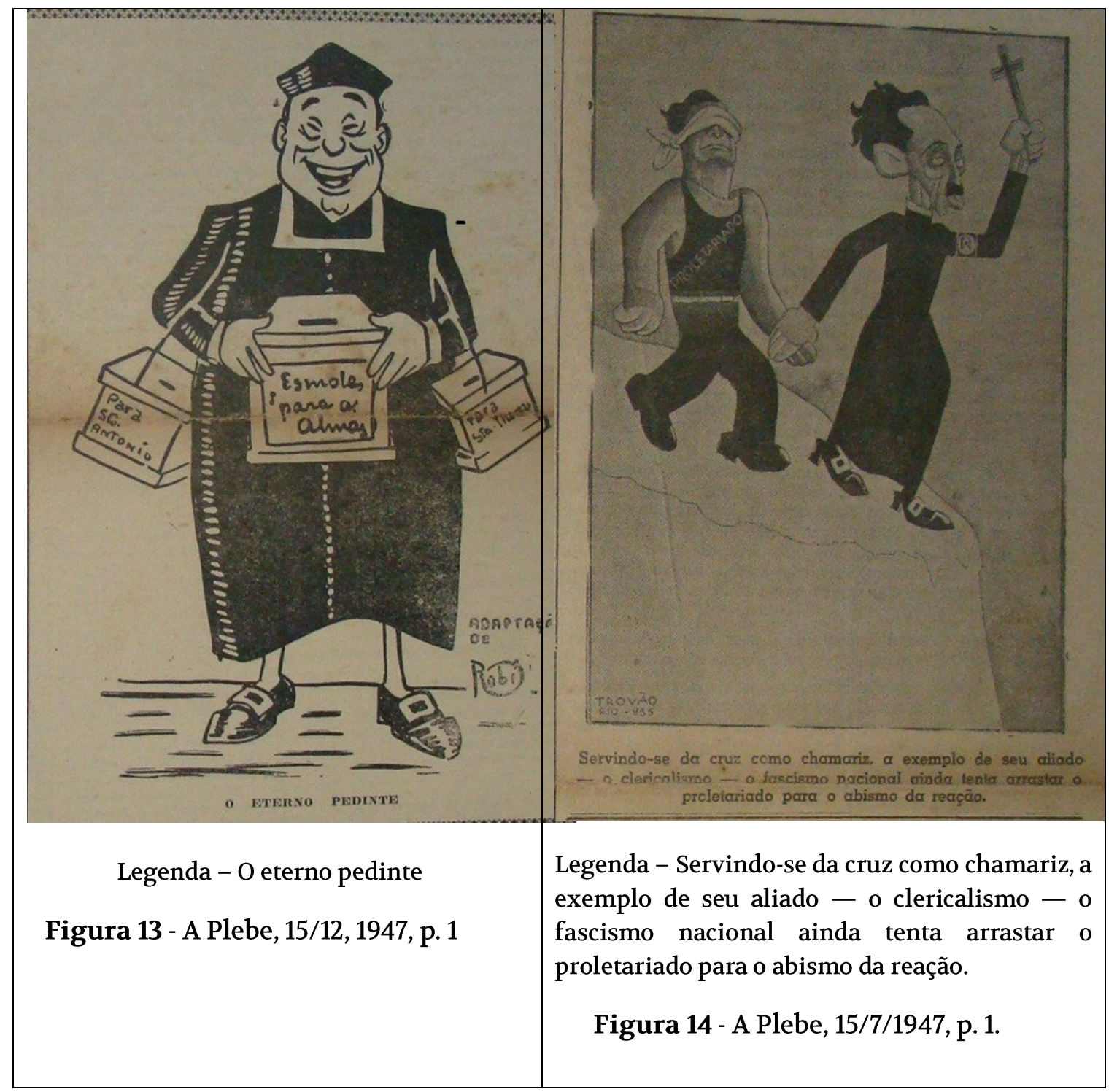

No ano seguinte, os temas das críticas são a alta hierarquia da Igreja Católica e a própria República brasileira que, nessa perspectiva, esqueceu os compromissos laicos e se enredou em alianças espúrias com aqueles que deveria combater. A charge de $1^{\circ}$ de maio de 1948 traz a cúpula da Igreja Católica (Papa, bispos, cardeais) plasmada em desenho de formas avantajadas. Os religiosos são homens obesos, flagrados em atitudes debochadas confabulando entre si perante um crucifixo de Cristo pendurado na parede. Nessa representação, as hierarquias são dissolvidas. Um deles está deitado numa poltrona, em total despojamento demonstrando intimidade entre os dirigentes da cúpula católica. Já a 
seguinte, de julho de 1948, a imagem caricata é uma jovem mulher, representando a República, em seus trajes consagrados pelos revolucionários de outros tempos à causa da liberdade e da igualdade. Nessa alegoria, a jovem República aparece em veste despojada e esvoaçante, seios à mostra, barrete frígio e descalça, símbolos claramente associados àquela imagem da jovem República dos sonhos e ideários revolucionários, inscritos e reafirmados na Revolução Francesa. Porém, logo o leitor perceberá que há sinais de que ela perdeu parte daqueles atributos, uma vez que o escudo e a lança, símbolos guerreiros e de suas disposições de luta, que ocupavam suas mãos, foram substituídos pelas mãos de um portavoz da alta hierarquia da Igreja Católica que esbanja satisfação ao caminhar à sua sombra.

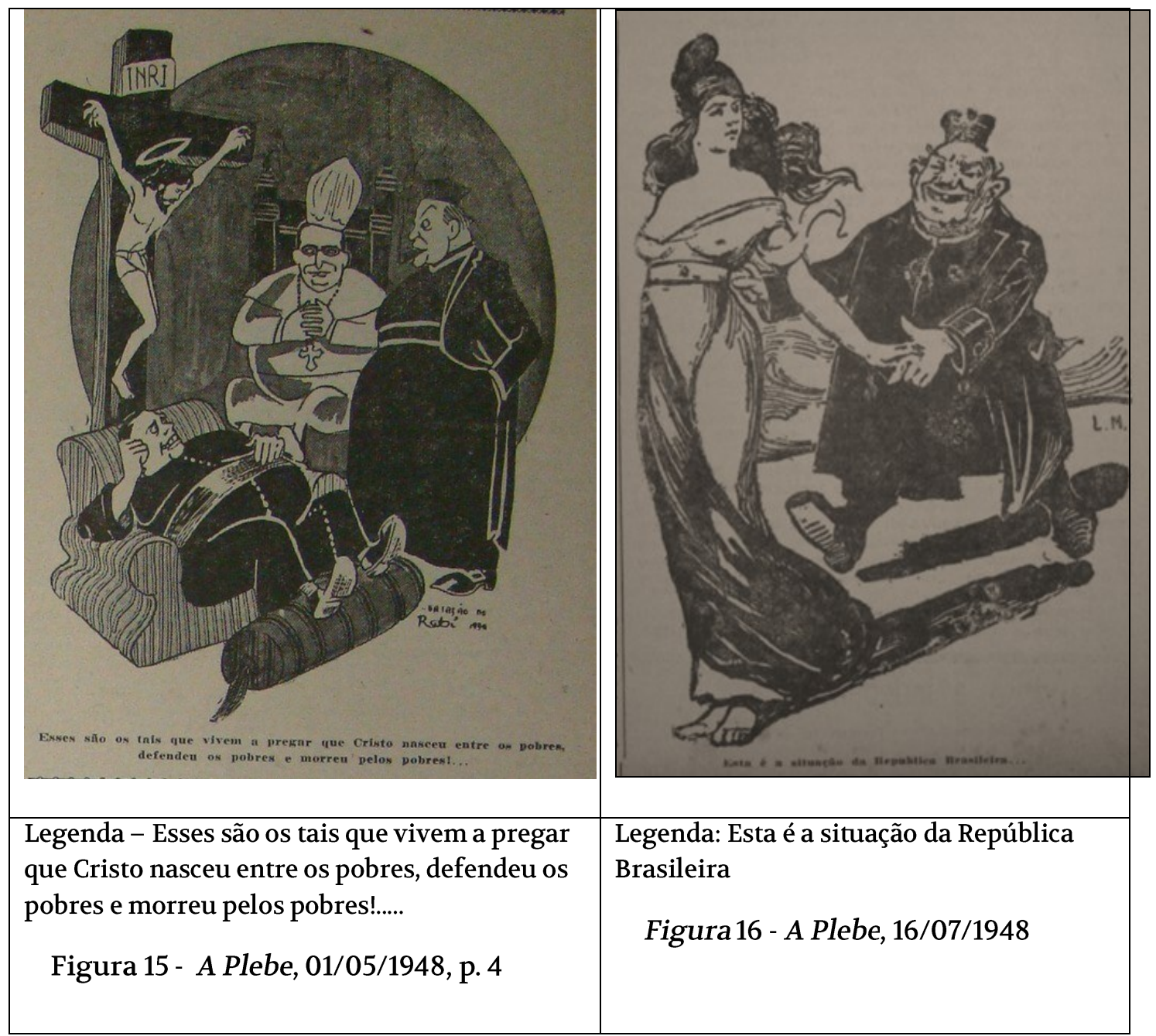

A legenda esclarece que "esta é a situação da República Brasileira", o que não deixará dúvidas ao leitor familiarizado com os códigos presentes na simbologia usada. Porém, há que se indagar se essa alegoria terá a mesma recepção por parte dos trabalhadores, os seus destinatários principais, uma vez que os códigos ali presentes supõem certa sofisticação e 
conhecimento histórico, decifração certamente obstaculizada pelo baixo grau de escolaridade do proletariado urbano brasileiro e paulistano ${ }^{18}$.

Novamente, a ação insidiosa da Igreja Católica é detalhada ainda nesse mesmo ano de 1948, quando A Plebe, na ilustração plasmada com base na metáfora de um polvo, caracteriza

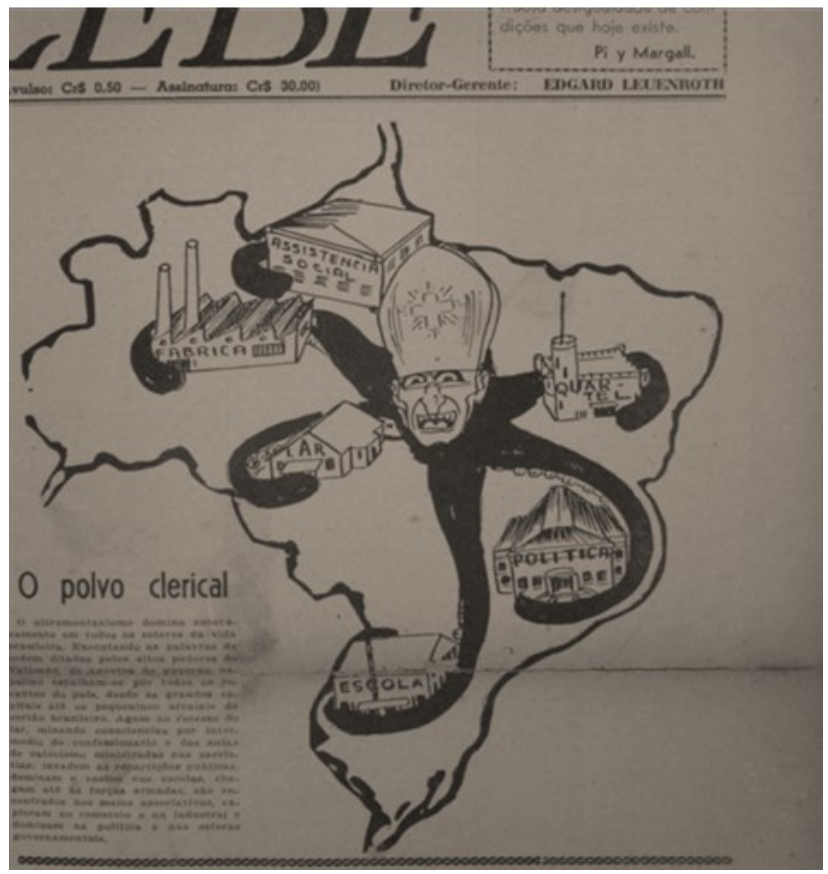
a ação da Igreja Católica. Nessa imagem, o mapa do Brasil tem em seu núcleo central a figura caricata de um "cardeal/papa", da qual saem os tentáculos, direcionados para todos os recantos do país, cujas garras aprisionam fortemente as instituições republicanas, públicas e privadas, como a Escola, as Fábricas, os Quartéis, o Lar e, as ações daí decorrentes tais como a Assistência Social e a Política.

Figura 17 - O Polvo Clerical - A Plebe, 15/01/1948, p. 1

Acompanha a imagem, logo abaixo da legenda "O polvo clerical", texto que discute o sentido dessa expansão que causa, nessa perspectiva, a contaminação da sociedade e do próprio Estado, em todas as suas esferas.

Para arrematar essas discussões, apresentamos um balanço dos temas veiculados em suas páginas nesses dois anos, baseando-se nas ilustrações que aparecem em seus textos que têm como perspectiva, na ótica de seus dirigentes (diretor/editor e colaboradores), debater certos temas da conjuntura e, também, de forma mais incisiva, expor os seus princípios doutrinários. Esses assuntos foram sistematizados nos gráficos abaixo (Gráficos 1 e 2), cuja incidência de temas presentes nos textos escritos e nas charges e ilustrações publicadas pelo jornal, voltam-se para as "liberdades" (política, de imprensa, de direitos sociais) e para a religião, que se expressa numa postura anticlerical e de combate à Igreja Católica, quer em termos doutrinários, quer em suas ramificações e ações na esfera pública e privada. Os atos dessas autoridades eclesiais são considerados indesejáveis, por tratar-se o Brasil de uma República laica, cujo perfil legal define-se pela separação entre Igreja e Estado.

${ }^{18}$ A alfabetização dos trabalhadores foi discutida de forma recorrente ao longo da República. O que chama à atenção é o descaso em relação ao assunto pelas autoridades. Na primeira República é recorrente a busca pela padronização do sistema escolar e a indicação das dificuldades para a efetiva implantação da escola pública, embora limitada. A carta magna de julho de 1934 institui a escola para todos, cuja implantação arrasta-se nas décadas seguintes. Ver sobre o assunto: (ROSSI, 2006, p. 128-141); (SILVA, 1999). 


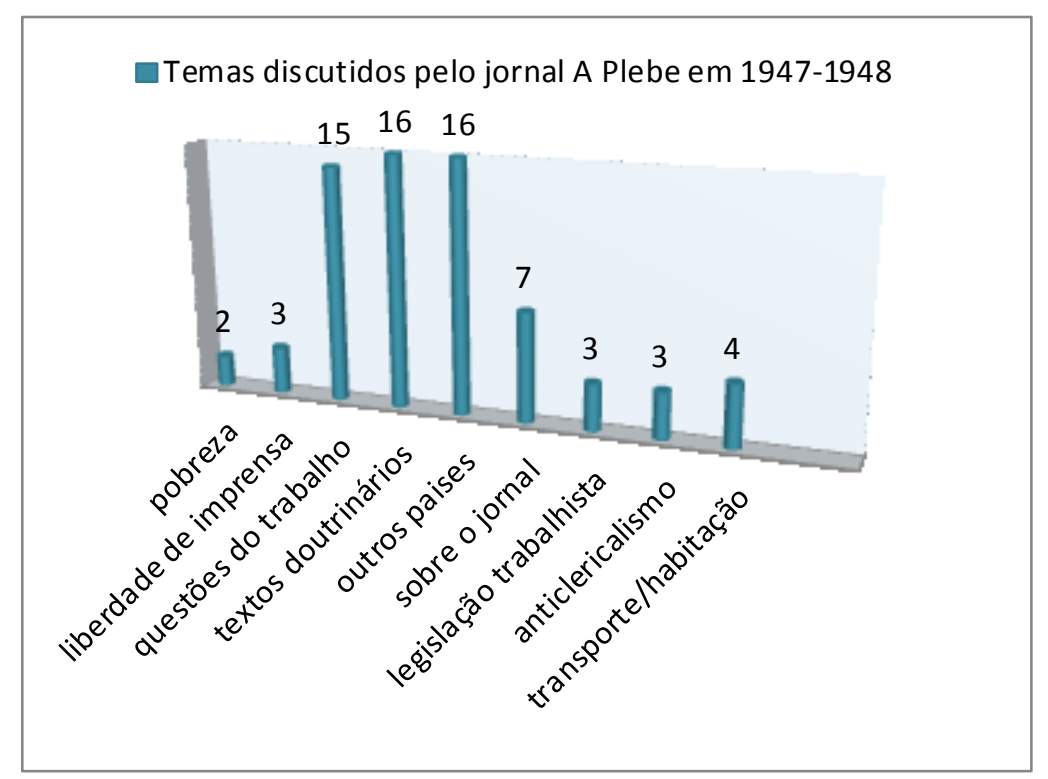

Gráfico 1 - Temas debatidos em A Plebe

O Gráfico 2, que apresenta o conjunto das imagens publicadas no periódico, permite-nos outras considerações, além daquelas já assinaladas topicamente. Merece reflexão os tipos desenhados pelos artistas do traço, que representam os burgueses e a alta hierarquia da Igreja Católica, articulados a certos assuntos que não provocam risos. $O$ exame mais acurado de seus traços e das expressões faciais não deixa dúvida de que se trata de imagens caricatas.

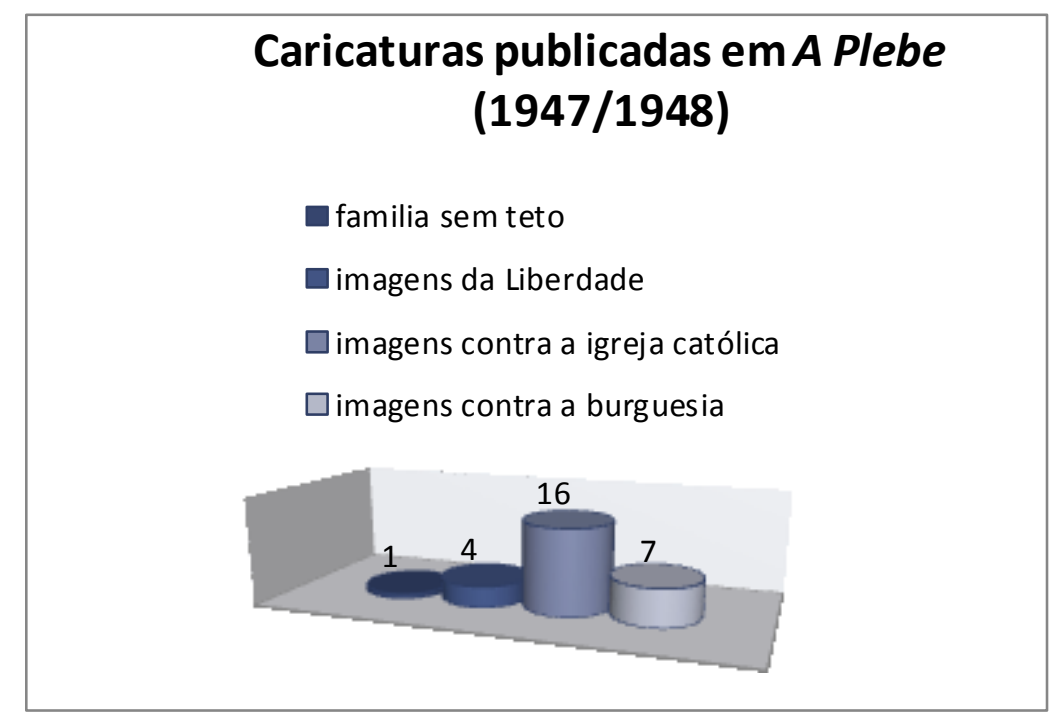

Gráfico 2 - Temas das imagens caricaturais em A Plebe 
Os traços do desenho podem ser lidos, seguindo as indicações de Gombrich (1995), na demarcação das expressões fisionômicas, carrancudas e tensas e não apenas no delineamento que conforma o formato do corpo ou no uso de metáforas com objetivo risível e de deboche. Nesses desenhos, as linhas faciais intentam plasmar sentimentos e valores subjetivos, como raiva, determinação, arrogância, astúcia; essas linhas densas e marcantes também aparecem na elaboração dos olhos que ora traduzem a malícia do ato do poder, ora a astúcia (Figura 7) e dureza no engendramento de suas estratégias de ação, presentes nos temas debatidos. Em contraposição a essas figuras, a Liberdade (Figuras, 6, 7 e 8) traz compleição corporal frágil, feições delicadas, até quando está em ato beligerante. Essa escolha também ocorre em relação às figuras dos trabalhadores que são delineadas em formas suaves em oposição aos protagonistas burgueses e seus aliados, sempre apresentados em formato caricatural expresso em sua deformação corporal e facial, nos gestos, nas roupas e adereços, indicando que os desenhos visam capturar, nos atos ali expressos, os seus valores subjacentes. Já os trabalhadores/pedinte, sempre magros e longilíneos (Figuras 1, 4 e 9), demonstram a sua fragilidade frente aos seus oponentes, mas também as possibilidades de rompimento dessa característica (fragilidade corporal) que se desdobra para a política, ao acenarem para o enfrentamento de seus inimigos, orientados pelos princípios libertários, cuja força encontra-se em sua organização, sob a bandeira da AIT. A exceção é o desenho de maio de 1949 (Figura 2) que além de referir-se a outro interlocutor - o povo - projeta-o com um porte forte e musculoso, indicando que se trata de uma síntese, o que explica a opção estética de ênfase ao volume corporal.

\section{Considerações finais}

Ao longo desse texto, procuramos discutir aspectos que foram abordados nas caricaturas e charges, publicadas pelo periódico A Plebe, de $1^{\circ}$ de maio de 1947 à mesma data de 1949, que marca "teoricamente" o último momento de atuação diretiva desse jornal por Edgard Leuenroth. É possível afirmar que essas imagens trazem os embates políticos travados pelo jornal, sob a direção mencionada, que agrega os libertários e que se voltam às questões gerais e específicas atinentes ao Brasil e aos trabalhadores brasileiros que manifestam os seus descontentamentos com as precárias condições de vida e os baixos salários. E, também, os caminhos para a superação da opressão, pelo engajamento em lutas diversas, no Brasil e no exterior, que vão dos movimentos grevistas às causas revolucionárias, ambos guiados pelos princípios libertários de ação direta.

Ao articular o grupo em torno dessa imprensa libertária e do Centro de Cultura Social, valendo-se de estratégias próprias, os seus integrantes acabam por estabelecer esfera pública própria, para debater questões doutrinárias e conjunturais de interesse dos 
trabalhadores, indicando os responsáveis por essa situação. Essa estratégia visava ampliar o seu raio de ação, a fim de conquistar outros adeptos para a causa libertária e, também, colocar-se (além de combate aos valores burgueses) como opção aos ideais e valores comunistas presentes na conjuntura.

A Plebe problematiza as múltiplas facetas dessa realidade atacando, de forma jocosa, os pilares do sistema capitalista ao indicar a burguesia, ávida e virulenta em seus propósitos e, a religião/Igreja católica, os protagonistas principais e responsáveis pelas mazelas vividas pelo conjunto dos expropriados, até mesmo de sua dignidade. As elites contra-atacam em várias frentes. Porém, o $1^{\circ}$ de maio sintetiza simbolicamente esses embates ao expressar a tentativa de redefinição de seu sentido: dia de celebração festiva em homenagem ao trabalhador em contraposição ao sentido dado pelas correntes políticas libertárias e trabalhistas como dia consagrado aos mártires do trabalho reverenciados pelo mundo afora.

Essas artimanhas foram desveladas pelo editor e colaboradores de $A$ Plebe, nesses dois anos, que se contrapõem às investidas de diluição das fronteiras de classe, ao demarcar os limites das liberdades de expressão e, também, as vigentes desigualdades sociais, referendadas pela Igreja Católica, cuja ação volta-se para a busca de coesão social, independente das desigualdades sociais e da miséria existentes na sociedade brasileira.

\section{Fontes}

A PLEBE. São Paulo: Grupo Editor, 1947-1949.

\section{Referências}

ANDREWS, George Reid. Imigração, 1890-1930. In: FERNANDES, Florestan. NEGROS e brancos em São Paulo (1888-1988). Bauru: EDUSC, 1998. p. 93-147.

BACZKO, Bronislaw. Imaginação social. In: Enciclopédia Einaudi. Lisboa: Imprensa Nacional-Casa da Moeda, 1986. v. 5, p.296-332..

BAKHTIN, Mikhail. A cultura popular na Idade Média e no Renascimento: o contexto de François Rabelais. São Paulo: HUCITEC/UnB, 1987.

BATALHA, Cláudio. A Historiografia da classe operária no Brasil: trajetória e tendências. In: FREITAS, Marcos Cezar (Org.). Historiografia brasileira em perspectiva. São Paulo: Contexto, 1998. p. 145-158. 
BILHÃO, Isabel. "Trabalhadores do Brasil!": as comemorações do Primeiro de Maio em tempos de estado novo varguista. Revista Brasileira de História, São Paulo, v. 31, n. 62, p. 7192, 2011.

CARVALHO, José. Murilo de. $A$ formação das almas: o imaginário da República no Brasil. São Paulo: Companhia das Letras, 1990.

CRUZ, Heloisa de Faria. São Paulo em papel e tinta: periodismo e vida urbana - 1890-1915. São Paulo: EDUC/FAPESP/Imprensa Oficial/Arquivo do Estado, 2000.

FAUSTO, Boris. Conflito social na república oligárquica: a greve de 1917. Estudos Cebrap, São Paulo, n. 10, p. 79-109, 1974.

FEREIRA, Maria Nazareth. A imprensa operária no Brasil. São Paulo: Ática, 1988.

FERREIRA, Jorge. A democratização de 1945 e o movimento queremista. In: FERREIRA, Jorge; DELAGADO, Lucilia (Org.). O Brasil republicano: o tempo da experiência democrática: da democratização de 1945 ao golpe civil-militar de 1964. Rio de Janeiro: Civilização Brasileira, 2003. p. 13-45.

GANTÚS, Fausta. Caricatura e poder político: crítica, censura y represión en la ciudad de México, 1876-1888. Mexico: El Colegio de Mexico. Instituto de Investigaciones Dr. José Maria Luis Mora, 2009.

GOMBRICH, Ernst Hans. Arte e ilusão: um estudo da Psicologia da representação pictórica. São Paulo: Martins Fontes, 1995.

GROSSMAN, Hadassa. A imagem da mulher na imprensa de esquerda no Brasil, 1889-1922: uma exposição sumária. Cadernos AEL, Campinas, n. 8/9, p. 8-9, 1998.

HARDMAN, Francisco Foot. Nem pátria, nem patrão. 3. ed. São Paulo: UNESP, 2002.

LESSER, Jeffrey. A negociação da identidade nacional: imigrantes, minorias e a luta pela etnicidade no Brasil. São Paulo: UNESP, 2001.

LUCA, Tania Regina de. História dos, nos e por meio dos periódicos. In: PINSKY, Carla Bassanesi. Fontes históricas. São Paulo: Contexto, 2005. p. 111-153.

LUCA, Tania Regina de; VIDAL, Laurent (Org.). Franceses no Brasil: séculos XIX e XX. São Paulo: UNESP, 2009.

NEGRO, Antonio Luigi; SILVA, Fernando Teixeira da. Trabalhadores, sindicatos e política. (1945-1964). In: FERREIRA, J. L.; DELGADO, Lucilia A. N. (Org.). O Brasil republicano: o tempo 


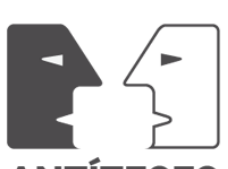

ANTÍTESES

da experiência democrática: da democratização de 1945 ao golpe civil-militar de 1964. Rio de Janeiro: Civilização Brasileira, 2003. p. 47-96.

POLLAK, Michael. Memória e identidade social. Estudos Históricos, Rio de Janeiro, v. 5, n. 10, p. 200-212, 1992.

PROPP, Vladimir. Comicidade e riso. São Paulo: Ática, 1992.

ROSSI, Ednéia Regina. Espaços de recepção e de criação de estratégias: a instituição escolar e a inserção das camadas populares na cultura letrada. São Paulo -1894-1923. Patrimônio e Memória, , v. 2, n. 1, p. 128-141, 2006. Disponível em: <http://pem.assis.unesp.br/index.php/pem/article/view/79>. Acesso em: 3 ago. 2012.

SILVA, Zélia Lopes da. A república dos anos 30: a sedução do moderno: novos atores em cena: industriais e trabalhadores na Constituinte de 1933-1934. Londrina: Eduel, 1999. 